\title{
Soybean hulls as feed substitute of ground corn can increase the fiber digestibility and bacterial fibrolytic profile of grazing Nellore steers during the rainy season
}

\author{
Casca de soja como substituto do milho moído pode aumentar a \\ digestibilidade da fibra e o perfil fibrolítico bacteriano de novilhos \\ Nelore em pastejo durante a estação chuvosa
}

\author{
Antônio Josê Neto ${ }^{1}$; Yury Tatiana Granja-Salcedo ${ }^{1 *}$; Juliana Duarte Messana ${ }^{1}$; \\ Euclides Braga Malheiros ${ }^{2}$; Ricardo Andrade Reis ${ }^{2}$; Alexandre Vaz Pires ${ }^{3}$; \\ Telma Teresinha Berchielli ${ }^{2}$
}

\begin{abstract}
This study aimed to evaluate the effect of replacement of ground corn by soybean hulls associated or not to whole soybean grain in the feed supplement on intake, nutrient digestibility, rumen microbial population, and fermentation parameters of growing Nellore steers grazing Brachiaria brizantha cv. Xaraés during rainy season. Were used eight castrated Nellore steers $(425 \pm 36 \mathrm{~kg}$ of body weight (BW)) fitted with ruminal and duodenal cannulas in a replicated $4 \times 4$ Latin square with a $2 \times 2$ factorial arrangement, allocated into 4 paddocks of 0.25 ha each, consisting of Brachiaria brizantha cv. Xaraés and supplemented with: (1) ground corn combined with whole soybean grain (SG); (2) ground corn without SG; (3) soybean hulls (SH) combined with SG; and (4) SH without SG. Supplement intake was no affected by SG or SH (mean $2.12 \mathrm{~kg}^{-1} \mathrm{~d}, P>0.05$ ). There were no interactions between $\mathrm{SH}$ and $\mathrm{SG}$ on $\mathrm{DM}$ and nutrients intake $(P>0.05)$. The addition of SG reduced the dry matter $(\mathrm{DM})$ intake expressed as \% of $\mathrm{BW}$ and $\mathrm{Kg}^{-1} \mathrm{~d}$, as well forage $\mathrm{DM}$, organic matter (OM), crude protein (CP), neutral detergent fiber (aNDF), and gross energy (GE) intake $(P \leq 0.01)$. Animals supplemented with SH without SG had greater digestibility of DM (74.52), OM (77.62), CP (77.51), NDF (71.93) and GE (72.90) than animals supplemented with $\mathrm{SH}$ with $\mathrm{SG}(\mathrm{DM}=69.01, \mathrm{OM}=71.92, \mathrm{CP}=72.81, \mathrm{NDF}=66.01, \mathrm{GE}$ $=68.01)$ expressed as $\%(P \leq 0.01)$. The addition of $\mathrm{SG}$ in the supplements declined the ruminal $\mathrm{pH}$ and $\mathrm{NH}_{3}-\mathrm{N}(P=0.02)$. Animals supplemented without SH without SG showed greater Entodinium counts $\left(6.01 \mathrm{n} \mathrm{x} 10^{4} \mathrm{ml}^{-1}, P=0.04\right)$, and SG supplementation decreased the numbers of Dasytricha, Isotricha, and ruminal total protozoa $(P<0.01)$. The abundance of Ruminococcus albus, R. flavefaciens, and Archaeas were higher for SH without SG supplement. Additionally, animals supplemented with SG had lower numbers of Fibrobacter succinogenes. The use of soybean hulls without whole soybean grain in the supplement may be effective to increase fiber digestibility, N retained, $R$. albus and $R$. flavefaciens in the rumen of Nellore steers grazing Brachiaria brizantha $\mathrm{cv}$. Xaraés during the rainy season.
\end{abstract}

Key words: Digestibility. Protozoa. Rumen bacteria. Tropical pasture. Whole soybean grain.

1 Pesquisadores, Departamento de Zootecnia, Faculdade de Ciências Agrárias e Veterinárias, Universidade Júlio de Mesquita Filho, Jaboticabal, SP, Brasil. E-mail: antoniojoseneto@yahoo.com.br; yurygranjasalcedo@gmail.com; duarte_juliana@hotmail.com

2 Profs., Departamento de Zootecnia, Faculdade de Ciências Agrárias e Veterinárias, UNESP, Jaboticabal, SP, Brasil. E-mail: euclides@fcav.unesp.br; rareis@fcav.unesp.br; telma.berchielli@unesp.br

3 Prof., Departamento de Zootecnia, Universidade de São Paulo, USP, Escola Superior de Agricultura "Luiz de Queiroz", Piracicaba, SP, Brasil. E-mail: pires.1@usp.br

Author for correspondence 


\section{Resumo}

Este estudo avaliou o efeito da substituição do milho moído por casca de soja associado ou não a grãos de soja no suplemento de novilhos Nelore em crescimento pastejando Brachiaria brizantha cv. Xaraés durante a estação chuvosa sobre o consumo, digestibilidade de nutrientes, população microbiana ruminal, e parâmetros de fermentação de novilhos Nelore (425 $\pm 36 \mathrm{~kg}$ de peso corporal (PC)) em crescimento pastejando Brachiaria brizantha cv. Xaraés durante a estação chuvosa. Foram utilizados oito novilhos Nelore com cânulas no rúmen e duodeno distribuídos em um quadrado latino $4 \times 4$ replicado com arranjo fatorial $2 \times 2$, alocados em 4 piquetes de 0.25 ha cada, de Brachiaria brizantha cv. Xaraés e suplementados com: (1) milho moído associado a grão de soja inteiro (SG); (2) milho moído sem SG; (3) casca de soja (SH) associada a SG; e (4) SH sem SG. O consumo de suplemento não foi afetado pela SG ou SH (média de $2,12 \mathrm{~kg}^{-1} \mathrm{~d}, P>0,05$ ). Não houve interação entre o SG e SH no consumo de MS e nutrientes $(P>0,05)$. A adição de SG diminuiu o consumo de matéria seca (MS) expresso em $\%$ de $\mathrm{PC}$ e $\mathrm{Kg}^{-1} \mathrm{~d}$, MS da forragem, matéria orgânica (MO), proteína bruta (PB), fibra em detergente neutro (FDN) e energia bruta (GE) $(P \leq 0.01)$. Animais suplementados com HS sem SG apresentaram maior digestibilidade da MS (74.52), MO (77.62), PB (77.51), FDN (71.93) e EB (72.90) do que animais suplementados com $\mathrm{SH}$ com $\mathrm{SG}(\mathrm{MS}=69.01, \mathrm{MO}=71.92, \mathrm{~PB}=72.81, \mathrm{FDN}=66.01, \mathrm{~EB}=$ $68.01)$ expresso em \% $(P \leq 0.01)$. A adição de $\mathrm{SG}$ nos suplementos diminuiu o $\mathrm{pH}$ e $\mathrm{NH}_{3}-\mathrm{N}$ ruminal $(P=0.02)$. Animais suplementados sem SH e sem SG mostraram grandes contagens de Entodinium (6.01 n x $\left.10^{4} \mathrm{ml}^{-1}, P=0.04\right)$, e a suplementação com SG reduziu os números de Dasytricha, Isotricha, e o total de protozoários ruminais $(P<0.01)$. A abundância de Ruminococcus albus, $R$. flavefaciens e Archaeas foi maior para SH sem suplementação com SG. Adicionalmente, animais suplementados com SG apresentaram menor número de Fibrobacter succinogenes. O uso de casca de soja sem grão de soja inteiro no suplemento pode ser eficaz para aumentar a digestibilidade da fibra, o $\mathrm{N}$ retido, e as populações de $R$. albus e $R$. flavefaciens no rúmen de novilhos Nelore pastejando Brachiaria brizantha cv. Xaraés durante a estação chuvosa.

Palavras-chave: Digestibilidade. Protozoários. Bactérias ruminais. Pastagem tropical. Grão de soja inteiro.

\section{Introduction}

Feed supplementation of grazing beef cattle is a valuable strategy to correct potential nutritional unbalances in tropical pastures. Several studies in beef cattle have shown the effects of diverse feed concentrates in the diet, such as corn processing (CORRIGAN et al., 2009), different energy sources (SCHRÖDER et al., 2003) and lipids inclusion (PATRA; YU, 2013). However, few studies have analyzed the rumen fermentation and microbial population of beef cattle grazing in tropical pastures, while dissociating the impact of energy intake due to the source of energy in the feed supplement.

Supplemental non-fibrous carbohydrates as starch can increases the feed intake and provides additional energy to grazing cattle on tropical pastures. Nonetheless, corn supplementation has been limited, due to the increase in global biofuel production, livestock and human utilization that have resulted in high prices of important feed grains for livestock (POPP et al., 2014). Consequently, the demand for alternative energy sources to corrects nutritional imbalances in grazing beef cattle have shown an important increasing.

Other source that improves energy balance and productive efficiency of beef cattle is the use of lipids in supplements. However, when beef cattle are supplemented with lipids, ruminal fermentation can be altered due to the toxicity of long-chain fatty acids, especially unsaturated fatty acids (UFA), to ruminal fibrolytic bacteria and methanogenic archaea (HENDERSON, 1973; JENKINS, 1993), resulting in lower fiber digestibility and DM intake, depending on the composition of basal diet. Thus, different nutritional strategies as whole soybean grain have been used to reduce the UFA effects on 
rumen microbes or ruminal fermentation parameters in beef cattle (GOMEZ-INSUASTI et al., 2014; GOMEZ-INSUASTI et al., 2018).

On the other hand, soybean hulls is a byproduct of soybean oil and soybean meal industry, that offer a potentially profitable pathway for strategies of grazing cattle supplementation. Previous reports in grazing cattle have shown that soybean hulls supplementation may increase crude protein digestibility and rumen population of Ruminococcus albus during dry season (NETO et al., 2017). Still there is lack in the evaluation of the effect of replacement of ground corn by soybean hulls associated or not to whole soybean grain in the supplements on rumen microbial population and fermentation parameters in grazing growing Nellore steers. Thus, this study aimed to evaluate the effect of substitution of corn by soybean hulls associated or not to soybean grain in the supplements on intake, nutrient digestibility, rumen microbial population, and fermentation parameters of growing Nellore steers grazing Brachiaria brizantha cv. Xaraés during rainy season. Our hypothesis is that soybean hulls associated with whole soybean grain could replace ground corn as a source of energy in the supplement of steers grazing during rainy season, without adversely affecting feed intake, fermentation parameters and ruminal microbiota.

\section{Material and Methods}

The protocol used in this experiment was in accordance with the Brazilian College of Animal Experimentation (Colégio Brasileiro de Experimentação Animal) guidelines and was approved by the Ethics, Bioethics, and Animal Welfare Committee (Comissão de Ética e Bem Estar Animal) of the Faculty of Agriculture and Veterinary Sciences - São Paulo State University (UNESP) - Jaboticabal campus (protocol number 021119/11).

\section{Animals and management}

The experiment was conducted at the UNESP (Jaboticabal, SP, Brazil) from December 2012 to May 2013, in the rainy season. Under the international Köppen classification this climate is characterized as tropical type AW with summer rains and relatively dry winter; the local altitude is $595 \mathrm{~m}$, at $21^{\circ} 15^{\prime} 22^{\prime \prime} \mathrm{S}, 48^{\circ} 18^{\prime} 58^{\prime \prime} \mathrm{W}$. The average maximum annual temperature is $29.1^{\circ} \mathrm{C}$, and the average minimum annual temperature is $16.5^{\circ} \mathrm{C}$. The average annual precipitation is $105 \mathrm{~mm}$, with $85 \%$ of the rainfall occurring between the months of October and March.

Areplicated $4 \times 4$ Latin square designexperimental using eight ruminal cannulated Nellore steers (425 $\pm 36 \mathrm{~kg}$, at $20 \mathrm{mo}$ of age) and four experimental periods in a $2 \times 2$ factorial arrangement, were used to evaluate the combined effects feed supplements with: (1) ground corn combined with soybean grain (SG); (2) ground corn without SG; (3) soybean hulls (SH) combined with SG; (4) $\mathrm{SH}$ without $\mathrm{SG}$, on intake, nutrient digestibility, ruminal fermentation parameters and ruminal microbiology over four $21 \mathrm{~d}$ periods. Each period consisted of $14 \mathrm{~d}$ for adaptation to the supplement and $7 \mathrm{~d}$ for sampling.

Initially, the animals were weighed, identified, and treated against ecto - and endoparasites by administration of ivermectin (Ivomec, Merial, Paulínia, BR), and allocated into 4 paddocks of 0.25 ha each, consisting of Brachiaria brizantha $\mathrm{cv}$. Xaraés. Pasture, used in this study, was established in 2011. Fertilizer was applied only once during entire the experimental period (February, 2013), 200 $\mathrm{kg}^{-1}$ ha of $\mathrm{N}: \mathrm{P}_{2} \mathrm{O}_{5}: \mathrm{K}_{2} \mathrm{O}$ (20:05:20). The paddocks were fitted with smooth wire fencing, waterers and a collective covered feed bunk to provide the supplement.

The proportion of ingredients and chemical composition of supplements are presented in Table 1. The supplements evaluated were ground corn combined with whole soybean grain (SG); ground 
corn without SG; soybean hulls $(\mathrm{SH})$ combined with SG; and SH without SG. All supplements contained $28 \%$ of DM of crude glycerin $(83.90 \%$ glycerol, $1.75 \%$ ether extract [EE], $4.30 \%$ ash, and $12.01 \%$ water) was acquired from a soybean-oil- based biodiesel production company (Cargill, Três Lagoas, Mato Grosso do 100 Sul, Brazil). This is a byproduct that can be used in ruminant diets without compromising intake and performance (DROUILLARD, 2012; PARSONS et al., 2009).

Table 1. Ingredients and chemical composition of feed supplements and pasture of Brachiaria brizantha cv. Xaraés.

\begin{tabular}{|c|c|c|c|c|c|}
\hline \multirow[b]{2}{*}{ Ingredients, \% of DM } & \multicolumn{2}{|c|}{ No soybean hulls } & \multicolumn{2}{|c|}{ Soybean hulls } & \multirow{2}{*}{ Pasture } \\
\hline & $\mathrm{SG}^{*}$ & No SG & SG & No SG & \\
\hline Ground corn & 8.90 & 18.50 & 0.00 & 0.00 & - \\
\hline Soybean meal & 0.00 & 49.0 & 0.00 & 49.0 & - \\
\hline Soybean hulls & 0.00 & 0.00 & 8.50 & 18.5 & - \\
\hline Whole soybean grain & 58.6 & 0.00 & 59.00 & 0.00 & - \\
\hline Crude glycerin & 28.00 & 28.00 & 28.00 & 28.0 & - \\
\hline Commercial premix ${ }^{\dagger}$ & 4.50 & 4.500 & 4.50 & 4.50 & - \\
\hline \multicolumn{6}{|c|}{ Chemical composition, \% of DM } \\
\hline Dry matter, & 90.90 & 88.10 & 90.20 & 88.20 & - \\
\hline Organic matter, & 91.70 & 89.51 & 90.91 & 89.22 & 92.71 \\
\hline Crude protein & 27.63 & 26.51 & 26.20 & 26.03 & 15.90 \\
\hline Neutral detergent fiber ${ }^{£}$ & 13.23 & 11.04 & 17.50 & 20.21 & 61.22 \\
\hline $\mathrm{Starch}^{\sharp}$ & 11.01 & 16.32 & 4.79 & 3.52 & - \\
\hline Ether extract & 13.84 & 3.18 & 13.44 & 2.57 & 1.31 \\
\hline Gross energy, $\mathrm{Mcal}^{-1} \mathrm{~kg}$ DM & 5.16 & 4.51 & 5.07 & 4.41 & 4.49 \\
\hline
\end{tabular}

${ }^{*}$ Whole soybean grain; ${ }^{\S}$ Average and standard deviation of the mean of samples obtained by technique of simulated grazing in five periods; ${ }^{\dagger}$ Composition $=120 \mathrm{~g}$ Calcium, 30 g phosphorus, $25 \mathrm{~g}$ sulfur, $80 \mathrm{~g}$ sodium, $330 \mathrm{mg}$ copper, 950 mg manganese, 1,220 $\mathrm{mg}$ zinc, $24 \mathrm{mg}$ iodine, $20 \mathrm{mg}$ cobalt, $6 \mathrm{mg}$ selenium, and $300 \mathrm{mg}$ fluorine; ${ }^{\mathfrak{f}=}$ assayed with a heat stable $\alpha$-amylase and expressed exclusive of residual ash; ${ }^{\star}$ Calculated based on ingredient values from Valadares Filho et al., 2010.

Animals were individually supplemented at the

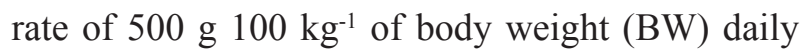
at 10:00 a.m. Individual steers BW was recorded at the initiation of each period without fasting period, to adjust the amount of supplement.

Forage mass in each paddock was estimated in each period during the grazing study. The average sward height was taken by reading 50 sampling points in each paddock, using a graduated stick in cm (BARTHRAM, 1985). Every $21 \mathrm{~d}$, the average sward height, was utilized for sampling 4 sites, where all forage included within the perimeter of the rising plate $\left(0.25 \mathrm{~m}^{2}\right)$ was collected by clipping at $5 \mathrm{~cm}$ above soil level from sites that represent the mean forage mass of paddock. The clipping samples were dried to a constant weight under forced air at $55^{\circ} \mathrm{C}$. Dry weights of these clippings were multiplied by the paddock area, to estimate the forage mass. Paddocks had an average forage mass of 10.3 ton $^{-1}$ ha $\pm 344 \mathrm{~kg}$ and an average sward height of $39.0 \mathrm{~cm} \pm 6.2$. The grazing method used was the continuous grazing system (ALLEN et al., 2011), and the initial average sward height was $47 \pm$ $5.9 \mathrm{~cm}$. Forage samples were collected during each period by the hand-plucking technique (JOHNSON, 1978).

Forage and concentrate samples were oven-dried at $55{ }^{\circ} \mathrm{C}$ for $72 \mathrm{~h}$ and ground by passage through a Wiley Mill $1 \mathrm{~mm}$ screen. 


\section{Proximate analysis}

The samples of ingredients, supplements, forage, and feces were analyzed for DM (method 934.01), OM (method 942.05), and EE (method 920.85) according to the Association of Official Analytical Chemists (AOAC, 1995). Concentrations of $\mathrm{N}$ were determined by rapid combustion $\left(850^{\circ} \mathrm{C}\right)$, conversion of all $\mathrm{N}$-combustion products to $\mathrm{N} 2$, and subsequent measurement by thermo conductivity cell (Leco ${ }^{\circledR} 125$ model FP-528; LECO Corporation, St. Joseph, MI). Crude protein was calculated as the percentage of $\mathrm{N}$ in the sample multiplied by 6.25 . The GE content of supplements, forage, and feces was determined using an adiabatic bomb calorimeter (model 6300; Parr Instrument Company, Moline, IL). Analyses for neutral detergent fiber (aNDF) were conducted using heat stable $\alpha$-amylase (Termamyl 2X, Novozymes, Araucária, BR), and without the addition of sodium sulfite, expressed inclusive of residual ash following Van Soest et al. (1991) and adapted for the Ankom200 Fiber Analyzer (Ankom Technology, Fairport, NY).

\section{Intake estimation}

Intake and nutrient digestibility were estimated in all periods using a marker method. Lignin isolated, purified, and enriched from Eucalyptus grandis $\left(\right.$ LIPE $\left.^{\circledR}\right)$ and indigestible neutral detergent fiber (iNDF) were used to estimate the excretion of fecal matter (as dry weight), and forage intake, respectively. The intake of concentrate was obtained through the individual supply of supplement, calculated according to the body weight of the animal.

External lignin isolated marker purified and enriched from Eucalyptus grandis (LIPE ${ }^{\circledR}$ - Simões Saliba Research products, Florestal, Brazil) was provided for $7 \mathrm{~d}$ by cannula infusion of a $500 \mathrm{mg}$ bolus, with $4 \mathrm{~d}$ to stabilize fecal excretion of the marker, and in the last $3 \mathrm{~d}$ for sample collection (SANTOS et al., 2011).
Fecal samples were collected on d 19, 20, and 21 of each periods, directly from the rectum, at 1100 and 1700, 0900 and 1500, and 0700 and $1300 \mathrm{~h}$, during the first, second, and third d of collection, respectively (BARROS et al., 2009). The fecal samples were dried at $55^{\circ} \mathrm{C}$ for $72 \mathrm{~h}$ and ground in a Wiley mill (Thomas Scientific, Swedesboro, NJ) to pass through a 1-mm screen and composited proportionately on each of $3 \mathrm{~d}$ and hours of sampling, within each animal, based on fecal dry weights. Approximately $10 \mathrm{~g}$ of each composited sample of feces was sent to the Federal University of Minas Gerais (Belo Horizonte, MG, Brazil) to analyse the lignin marker concentration using the infrared spectroscopy method (SALIBA et al., 2013).

The samples of feces, forage, and concentrate were placed in Ankom bags (Filter bag F57; Ankom Technology Corporation, Fairport, NY) and incubated in the rumen of a cannulated Nellore animal for a period of $288 \mathrm{~h}$ (VALENTE et al., 2011). When the bags were withdrawn from the rumen, they were soaked in water for $30 \mathrm{~min}$ and gently washed by hand under running water until the wash water ran clear. The bags were then placed in an Ankom200 fiber Analyzer (Ankom Technology, Fairport, NY, USA), according to the methods described by Van Soest et al. (1991), and the iNDF was determined by weighing the bags with a digital scale after drying them in an oven, first at $55^{\circ} \mathrm{C}$ for $72 \mathrm{~h}$ and then at $105^{\circ} \mathrm{C}$ for $12 \mathrm{~h}$. The residue was considered as iNDF. Individual forage intakes were estimated by subtracting marker excretion from the concentrate from the total iNDF excretion and dividing that difference by the concentration of the marker in the forage.

\section{Ruminal fermentation}

Rumen $\mathrm{pH}$, ammonia $\mathrm{N}\left(\mathrm{NH}_{3}-\mathrm{N}\right)$, and volatile fatty acids (VFA) were measured d 18 of each period, when rumen fluid samples (around $80 \mathrm{~mL}$ ) were collected manually at $0,3,6,12$ and $18 \mathrm{~h}$ after 
supplementation (1000 h). Rumen fluid (liquid and solid phase) was obtained from several sites within the rumen and was subsequently strained through two layers of cheesecloth. Immediately after collection, the $\mathrm{pH}$ of rumen fluid was determined using a digital potentiometer (ORION 710A, Boston, MA). An aliquot of collected fluid $(50 \mathrm{~mL})$ was poured into plastic bottle and frozen at $-20^{\circ} \mathrm{C}$ for subsequent analysis of $\mathrm{NH}_{3}-\mathrm{N}$ concentration. Ruminal fluid $\mathrm{NH}_{3}-\mathrm{N}$ was analyzed by distilling with $2 \mathrm{M} \mathrm{KOH}$ in a micro-Kjeldahl system, according to the original procedures of Fenner (1965). The samples collected for analysis of VFA were centrifuged at $13,000 \times \mathrm{g}\left(4^{\circ} \mathrm{C}\right)$ for $30 \mathrm{~min}$ and quantified by gas chromatography (GC Shimatzu model 20-10, automatic injection) 174 using capilar column (SP-2560, $100 \mathrm{~m} \times 0.25 \mathrm{~mm}$ in diameter and $0.02 \mathrm{~mm}$ in thickness, Supelco, Bellefonte, PA) according to the methodology of Palmquist and Conrad (1971).

\section{Rumen microbial profile}

Ruminal microbiology (bacteria and protozoa) samples were collected on day 18, $3 \mathrm{~h}$ after supplementation. For protozoa population cell counts were obtained from rumen content aliquots that were preserved in formalin (a solution of equal parts water and $370 \mathrm{~mL}^{-1} \mathrm{~L}$ formaldehyde) according to D'Agosto and Carneiro (1999). Ciliate protozoa species were identified and quantified the in-chamber Sedgewick-Rafter, according to Dehority (1984).

For the quantification and identification of rumen bacteria, fifty grams of the ruminal contents (liquid and solid fraction) were weighed and immediately processed to obtain a bacterial pellet as describe by Granja-Salcedo et al. (2017a). DNA extraction was conducted in $250 \mathrm{mg}$ of bacterial pellet using the extraction FastDNA ${ }^{\circledR}$ SPIN Kit for Soil and FastPrep ${ }^{\circledR}$ Instrument (MP Biomedical, LLC). The integrity of the DNA was checked by electrophoresis on agarose gel $(0.8 \%)$. Complementary DNA was assessed by spectrophotometry (Thermo Scientific NanoDrop ${ }^{\mathrm{TM}}$ 1000) for evaluation of its quality and quantity. For quantification of bacteria species important for fiber degradation (Fibrobacter succinogenes, $R$. albus, $R$. flavefaciens) starch digestion (Selenomonas ruminantium), ruminal lipid metabolism (Anaerovibrio lipolytica) and rumen methanogens (Archaea), the technique used was qPCR. The primers used in this study are shown in Table 2.

Three concentrations $(400,600$, and $800 \mathrm{nM})$ of forward and reverse primers were tested to determine minimum primer concentration giving the lowest threshold cycle and to reduce nonspecific amplification before starting the reaction. In addition, for each primer set were determined the slope value, from which the efficiency was calculated. The validation of the selected-primers concentrations was performed with different concentrations of DNA $(150,125,100,50$, and $25 \mathrm{ng})$.

The amplifications were performed in triplicate and negative controls were run in the assay, omitting the total DNA. The reactions were conducted in the 7500 Real Time PCR System. Rox was used as a passive reference dye. The qPCR reaction was carried out using $100 \mathrm{ng}$ of total DNA in a reaction containing: $6.25 \mu \mathrm{L}$ of SYBR ${ }^{\circledR}$ Green PCR Master Mix (Bio-Rad, Hercules, California, USA), 10 pmol of primer pair, and ultrapure water to a final volume of $12.5 \mu \mathrm{L}$. Cycling conditions were $50^{\circ} \mathrm{C}$ for $2 \mathrm{~min} ; 95^{\circ} \mathrm{C}$ for $10 \mathrm{~min}$; and 40 cycles of $95^{\circ} \mathrm{C}$ for 15 seconds, $60^{\circ} \mathrm{C}$ for $1 \mathrm{~min}$, and $78^{\circ} \mathrm{C}$ for 30 seconds. After amplification cycles, a step was added in which temperature was increased from 60 to $95^{\circ} \mathrm{C}$ to obtain dissociation curve of the reaction products, used for analyzing the specificity of amplification. Relative quantification was used to determine species proportion; the total $16 \mathrm{~S}$ rRNA gene amplified by the general bacterial primer set was used for normalization of the data (DENMAN; MCSWEENEY, 2006). The results were expressed 
as a $16 \mathrm{~S}$ rDNA ratio of general bacteria, following the equation:

Relative quantification $=2-(\mathrm{Ct}$ target $-\mathrm{Ct}$ total bacteria);
Where $\mathrm{Ct}$ was defined as the number of cycles required for the fluorescent signal to cross the threshold.

Table 2. PCR primers used in this study for the quantification of specific rumen microbes by qPCR.

\begin{tabular}{|c|c|c|c|}
\hline Primer & Sequence ( $5^{\prime}$ to $\left.3^{\prime}\right)$ & $\begin{array}{l}\text { Product size } \\
\quad(\mathrm{bp})\end{array}$ & $\begin{array}{c}\text { Efficiency } \\
(\%)\end{array}$ \\
\hline Total bacteria $^{* \dagger}$ & $\begin{array}{l}\text { F: CGGCAACGACAACCC } \\
\text { R: CCATTGTAGCACCTGTGTAGCC }\end{array}$ & 130 & 99 \\
\hline Fibrobacter succinogenes ${ }^{\dagger}$ & $\begin{array}{l}\text { F: GGTATGGGATGAGCTTGC } \\
\text { R: GCCTGCCCCTGAACTATC }\end{array}$ & 121 & 95 \\
\hline Ruminococcus flavefasciens ${ }^{\dagger}$ & $\begin{array}{l}\text { F: GGACGATAATGACGGTACTT } \\
\text { R: GCAATC(CT)GAACTGGGACAAT }\end{array}$ & 132 & 96 \\
\hline $\begin{array}{l}\text { Ruminococcus } \\
\text { albus }^{\dagger}\end{array}$ & $\begin{array}{l}\text { F: CCCTAAAAGCAGTCTTAGTTCG } \\
\text { R: CCTCCTTGCGGTTAGAACA }\end{array}$ & 175 & 96 \\
\hline Total Archaeas & $\begin{array}{l}\text { F: TTC GGT GGA TCD CAR AGR GC } \\
\text { R:GBA RGT CGW AWC CGT AGA ATC C }\end{array}$ & 140 & 94 \\
\hline Anaerovibrio lipolytica ${ }^{\S}$ & $\begin{array}{l}\text { F:TTGGGTGTTAGAAATGGATTCTAGTG } \\
\text { R:TCGAAATGT TGTCCCCAT CTG }\end{array}$ & 82 & 98 \\
\hline Selenomonas ruminantium ${ }^{\infty}$ & $\begin{array}{l}\text { F:GGCGGGAAGGCAAGTCAGTC } \\
\text { R:CCTCTCCTGCACTCAAGAAAGACAG }\end{array}$ & 83 & 96 \\
\hline
\end{tabular}

"Primers used for qPCR normalization; F = "forward"; R = "reverse". 'Denman and McSweeney (2006). `Denman, et al. (2007). ${ }^{\S}$ Fuentes et al. (2009). ${ }^{\infty}$ Khafipour et al. (2009).

\section{Microbial protein yield}

To determine the microbial protein yield, spot samples of urine were estimated by total excretion of purine derivatives through spontaneous urination collection on d 21 of each experimental period, 4 $\mathrm{h}$ after of supplementation. Urine samples were filtered through cheesecloth and aliquots of $10 \mathrm{~mL}$ were diluted in $40 \mathrm{~mL}$ of sulfuric acid at $0.036 \mathrm{~N}$ to avoid bacterial degradation of purine derivatives and uric acid precipitation (VALADARES et al., 1999), and subsequently intended for the quantification of urinary levels of urea nitrogen, creatinine, allantoin.

Allantoin was analyzed according to the method described by Chen and Gomes (1992). The final point colorimetric method was used to determine uric acid concentrations in urine (Labtest Diagnostic S.A., Lagoa Santa, Brazil). The total excretion of purine derivatives was calculated from the sum of the quantities of allantoin and uric acid excreted in the urine, expressed as $\mathrm{mmol}^{-1} \mathrm{~d}$. The microbial efficiency was calculated as total microbial biomass per TDN intake (NRC, 2000).

Urine volume was estimated according to Chizzotti et al. (2008). Urinary creatinine excretion (UCE) was related with the shrunk body weight (SBW) and estimated according to Costa e Silva et al. (2012).

Samples of feces and urine were evaluated for nitrogen content using a LECO FP-528 nitrogen analyzer (LECO Corp., St. Joseph, MI). The amount of nitrogen absorbed was obtained from the difference between the nitrogen ingested and the nitrogen excreted in the feces, whereas the Nitrogen balance $\left(\mathrm{N}\right.$ retained, $\left.\mathrm{g}^{-1} \mathrm{~d}\right)$. 


\section{Statistical analysis}

Data of intake, apparent digestibility, protozoa and bacteria population were analyzed using the MIXED procedures (SAS ${ }^{\circledR}$ software, SAS Inst. Inc., Cary, NC, USA), considering a replicated $4 \times 4$ Latin square (four treatments and four periods), with a $\mathrm{Ax}$ $\mathrm{B}$ factorial arrangement. The fixed effect of factor A corresponds to the soybean hulls provision (yes or no), and factor B to the soybean grain provision (yes or no). The model included the fixed effect of factor $\mathrm{A}$, factor $\mathrm{B}$, factors interactions and treatments error; the random effects of Latin square, experimental period, animal, and residues corresponding to the model. Data of protozoa were transformed to $\log 10$, plus a drive to meet the requirements of the SAS analysis.

Data of $\mathrm{pH}, \mathrm{NH}_{3}-\mathrm{N}$, and VFA analysis of variance also includes a model with repeated measures overtime and the model included the fixed effect of factor A, factor B, sampling time and its interactions; the random effects of Latin square, period, animal, and residues corresponding to the model.

Normality and homoscedasticity of the data was verified using the UNIVARIATE procedure of SAS. Studentized residuals were plotted against the predicted values using the plot procedure to analyze data for outliers. The LSMEANS statement of the mixed procedure of SAS was used to calculate mean values. When the treatments were significant, the means were compared with Tukey tests using the
PDIFF option in LSMEANS command. The level of significance used to assess differences among means was $\alpha=0.05$.

\section{Results}

Supplement intake was no affected by SG or $\mathrm{SH}$ (mean $2.12 \mathrm{~kg}^{-1} \mathrm{~d}, P>0.05$ ). There were no interactions between $\mathrm{SH}$ and $\mathrm{SG}$ provision in the supplement regarding intake of DM (\% of $\mathrm{BW} ; \mathrm{kg}^{-1} \mathrm{~d}$ ), forage DM, supplement DM, OM, $\mathrm{CP}$, aNDF, EE and GE. There were no effects of SH supplementation on intake of DM, forage $\mathrm{DM}$, supplement DM, OM, CP, aNDF, EE, and GE. However, the addition of SG decreased the intake of DM, forage DM, OM, CP, aNDF, GE and increased the $\mathrm{EE}$ intake $(\mathrm{SG}=0.35$, No $\mathrm{SG}=$ $0.18 \mathrm{~kg}^{-1} \mathrm{~d}$ ) (Table 3). Animals supplemented with SH without SG had greater digestibility of DM (74.52), OM (77.62), CP (77.51), NDF (71.93) and GE (72.90) than animals supplemented with SH with $\mathrm{SG}(\mathrm{DM}=69.01, \mathrm{OM}=71.92, \mathrm{CP}=$ $72.81, \mathrm{NDF}=66.01, \mathrm{GE}=68.01)$ expressed as \% $(P \leq 0.01)$. Consequently, the digestibility of aNDF increased at $8.0 \%$ for animals supplemented with SH without SG (Table 3).

There was not interaction between sampling time $x \mathrm{SH} \times \mathrm{SG}$ on ruminal $\mathrm{pH}, \mathrm{NH}_{3}-\mathrm{N}$ and VFA concentrations of Nellore on pasture during growing phase (Table 4, $P>0.05$ ). However, the addition of $\mathrm{SG}$ in the supplements decreased the $\mathrm{pH}$ and $\mathrm{NH}_{3}-\mathrm{N}(P=0.02)$.

Table 3. Effect of replacement of ground corn by soybean hulls (SH) associated or not to whole soybean grain (SG) on diet intake and digestibility in grazing Nellore steers during rainy season.

\begin{tabular}{|c|c|c|c|c|c|c|c|c|}
\hline & \multicolumn{2}{|c|}{ No SH } & \multicolumn{2}{|c|}{$\mathrm{SH}$} & \multirow{2}{*}{ SEM } & \multicolumn{3}{|c|}{ P-value $^{\dagger}$} \\
\hline & SG & No SG & SG & No SG & & SH & $\mathrm{SG}$ & $\mathrm{SH} \times \mathrm{SG}$ \\
\hline Intake, $\%$ of $\mathrm{BW}^{*}$ & & & & & & & & \\
\hline $\begin{array}{l}\text { Dry matter } \\
\text { Intake, } \mathrm{kg}^{-1} \mathrm{~d}\end{array}$ & 2.10 & 2.29 & 2.00 & 2.47 & 0.11 & 0.69 & $<0.01$ & 0.20 \\
\hline Dry matter & 8.88 & 9.53 & 8.57 & 10.60 & 0.54 & 0.43 & 0.01 & 0.16 \\
\hline Forage DM & 6.78 & 7.43 & 6.42 & 8.46 & 0.52 & 0.48 & $<0.01$ & 0.15 \\
\hline Suppl. DM & 2.10 & 2.09 & 2.15 & 2.15 & 0.09 & 0.65 & 0.82 & 0.66 \\
\hline
\end{tabular}


continuation

\begin{tabular}{lcccccccc} 
Organic matter & 8.20 & 8.77 & 7.91 & 10.0 & 0.52 & 0.32 & 0.01 & 0.12 \\
Crude protein & 1.68 & 1.74 & 1.58 & 1.98 & 0.14 & 0.48 & 0.02 & 0.08 \\
NDF $^{£}$ & 4.33 & 4.80 & 4.35 & 5.76 & 0.29 & 0.11 & $<0.01$ & 0.12 \\
Extract ether & 0.36 & 0.18 & 0.35 & 0.18 & 0.02 & 0.75 & $<.01$ & 0.53 \\
Gross energy, Mcal' ${ }^{-1} \mathrm{~d}$ & 40.91 & 43.82 & 39.80 & 48.05 & 2.51 & 0.43 & 0.01 & 0.20 \\
Digestibility, \% & & & & & & & \\
Dry matter & $71.81^{\mathrm{b}}$ & $71.25^{\mathrm{bc}}$ & $69.01^{\mathrm{c}}$ & $74.52^{\mathrm{a}}$ & 1.42 & 0.77 & 0.01 & $<0.01$ \\
Organic matter & $73.90^{\mathrm{b}}$ & $73.35^{\mathrm{b}}$ & $71.92^{\mathrm{b}}$ & $77.62^{\mathrm{a}}$ & 1.28 & 0.31 & 0.01 & $<0.01$ \\
Crude protein & $76.73^{\mathrm{ab}}$ & $74.50^{\mathrm{ab}}$ & $72.81^{\mathrm{b}}$ & $77.51^{\mathrm{a}}$ & 1.98 & 0.80 & 0.19 & $<0.01$ \\
Neutral detergent fiber & $67.14^{\mathrm{b}}$ & $65.81^{\mathrm{b}}$ & $66.01^{\mathrm{b}}$ & $71.93^{\mathrm{a}}$ & 1.89 & 0.07 & 0.09 & 0.01 \\
Extract ether & 79.45 & 63.42 & 73.25 & 66.94 & 6.48 & 0.79 & 0.04 & 0.36 \\
Gross energy & $70.93^{\mathrm{ab}}$ & $70.84^{\mathrm{ab}}$ & $68.01^{\mathrm{b}}$ & $72.90^{\mathrm{a}}$ & 1.39 & 0.77 & 0.01 & 0.01 \\
\hline
\end{tabular}

$\dagger=\mathrm{SH}$, soybean hulls addition effect; $\mathrm{SG}$, whole soybean grain addition effect; ${ }^{*} \mathrm{BW}=$ body weight; ${ }^{\mathrm{a}, \mathrm{b}, \mathrm{c}=}$ Means within a row with different superscripts (lower case) differ $(\mathrm{P}<0.05)$ by Tukey tests; ${ }^{£=}$ assayed with a heat stable $\alpha$-amylase and expressed exclusive of residual ash.

Table 4. Effect of replacement of ground corn by soybean hulls (SH) associated or not to whole soybean grain (SG) on rumen fermentation parameters in grazing Nellore steers during rainy season.

\begin{tabular}{|c|c|c|c|c|c|c|c|c|c|}
\hline & \multicolumn{2}{|c|}{ No SH } & \multicolumn{2}{|c|}{$\mathrm{SH}$} & \multirow{2}{*}{ SEM } & \multicolumn{4}{|c|}{ P-value ${ }^{\dagger}$} \\
\hline & SG & No SG & $\mathrm{SG}$ & No SG & & $\mathrm{SH}$ & $\mathrm{SG}$ & $\mathrm{SH} * \mathrm{SG}$ & $\mathrm{T}^{*} \mathrm{SH}^{*} \mathrm{SG}$ \\
\hline $\mathrm{pH}$ & 6.46 & 6.52 & 6.41 & 6.53 & 0.05 & 0.73 & 0.02 & 0.30 & 0.09 \\
\hline $\begin{array}{l}\mathrm{NH}_{3}-\mathrm{N}, \mathrm{mg}^{-1} \mathrm{dL} \\
V F A^{£}, m M\end{array}$ & 12.50 & 14.12 & 12.44 & 13.62 & 1.31 & 0.59 & 0.02 & 0.77 & 0.12 \\
\hline Total VFA ${ }^{£}$ & 78.65 & 78.23 & 78.25 & 79.04 & 8.35 & 0.96 & 0.93 & 0.73 & 0.18 \\
\hline Acetate & 48.54 & 48.32 & 48.25 & 50.14 & 5.46 & 0.69 & 0.67 & 0.35 & 0.11 \\
\hline Propionate & 15.50 & 15.14 & 15.51 & 14.83 & 1.97 & 0.88 & 0.37 & 0.76 & 0.13 \\
\hline Butyrate & 10.91 & 11.33 & 11.02 & 10.55 & 0.92 & 0.65 & 0.84 & 0.06 & 0.15 \\
\hline Isobutyrate & 0.97 & 1.05 & 0.91 & 0.94 & 0.06 & 0.01 & 0.16 & 0.47 & 0.17 \\
\hline Valerate & 1.14 & 1.08 & 1.12 & 1.02 & 0.08 & 0.60 & 0.13 & 0.50 & 0.19 \\
\hline Isovalerate & 1.46 & 1.57 & 1.40 & 1.44 & 0.12 & 0.27 & 0.33 & 0.51 & 0.12 \\
\hline A:P ratio & 3.41 & 3.58 & 3.36 & 3.59 & 0.42 & 0.89 & 0.09 & 0.54 & 0.09 \\
\hline
\end{tabular}

$\ddagger=$ Acetate to propionate ratio; ${ }^{\uparrow=} \mathrm{SH}$, soybean hulls addition effect; $\mathrm{SG}$, whole soybean grain addition effect; $\mathrm{T}=$ time effect. ${ }^{\mathfrak{}}=$ Volatile fatty acids.

There were no interactions between $\mathrm{SH}$ and SG supplementation on numbers of Dasytricha, Isotricha, Polyplastron, Ostracodinium, and total protozoa (Table 5, P>0.05). However, there was interaction between $\mathrm{SH}$ and SG supplementation on Entodinium population; Animals supplemented without SH without SG showed greater Entodinium

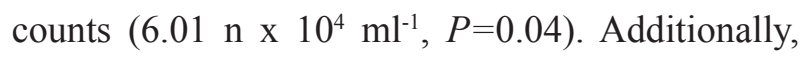
SG supplementation decreased the numbers of Dasytricha, Isotricha, and ruminal total protozoa $(P<0.01)$. 
Table 5. Effect of replacement of ground corn by soybean hulls (SH) associated or not to whole soybean grain (SG) on rumen fluid protozoa numbers in grazing Nellore steers during rainy season.

\begin{tabular}{|c|c|c|c|c|c|c|c|c|}
\hline \multirow{2}{*}{ Protozoa $\left(\mathrm{n} \mathrm{x} 10^{4} \mathrm{ml}^{-1}\right)$} & \multicolumn{2}{|c|}{ No SH } & \multicolumn{2}{|c|}{$\mathrm{SH}$} & \multirow{2}{*}{ SEM } & \multicolumn{3}{|c|}{ P-value ${ }^{\dagger}$} \\
\hline & SG & No SG & SG & No SG & & $\mathrm{SH}$ & SG & $\mathrm{SH} * \mathrm{SG}$ \\
\hline Entodinium & $5.70^{\mathrm{b}}$ & $6.01^{\mathrm{a}}$ & $5.56^{\mathrm{b}}$ & $5.60^{\mathrm{b}}$ & 0.07 & $<0.01$ & 0.01 & 0.04 \\
\hline Dasytricha & 4.27 & 4.87 & 4.18 & 4.81 & 0.13 & 0.64 & $<0.01$ & 0.89 \\
\hline Isotricha & 3.79 & 4.06 & 3.47 & 4.01 & 0.17 & 0.30 & $<0.01$ & 0.26 \\
\hline Polyplastron & 3.88 & 4.15 & 3.79 & 3.81 & 0.14 & 0.13 & 0.25 & 0.33 \\
\hline Ostracodinium & 3.62 & 3.95 & 3.81 & 3.84 & 0.15 & 0.79 & 0.18 & 0.26 \\
\hline Total protozoa & 18.51 & 22.01 & 17.11 & 21.10 & 0.93 & 0.26 & $<0.01$ & 0.93 \\
\hline
\end{tabular}

${ }^{\dagger} \log ^{10}$ of number of protozoa; ${ }^{\text {a,b, } c=}$ Means within a row with different superscripts (lower case) differ $(\mathrm{P}<0.05)$ by Tukey tests; ${ }^{\dagger=}$ $\mathrm{SH}$, soybean hulls addition effect; SG, whole soybean grain addition effect.

Rumen bacterial population was affected by SG $\times$ SG interaction except Fibrobacter succinogenes and Selenomonas ruminantium (Table 6). The relative abundance of Ruminococcus albus, $R$. flavefaciens, and Archaea was higher for $\mathrm{SH}$ without SG diets $(P<0.01)$. Additionally, animals supplemented with SG decreased the abundance of $F$. succinogenes and S. ruminantium $(P<0.01)$. On the other hand, supplements without $\mathrm{SH}$ increased the population of $S$. ruminantium $(P=0.03)$.

Table 6. Effect of replacement of ground corn by soybean hulls (SH) associated or not to whole soybean grain (SG) on relative abundance (\%) of cellulolytic bacteria and methanogenic Archaeas in grazing Nellore steers during rainy season.

\begin{tabular}{|c|c|c|c|c|c|c|c|c|}
\hline \multirow{2}{*}{ Item } & \multicolumn{2}{|c|}{ No SH } & \multicolumn{2}{|c|}{ SH } & \multirow{2}{*}{ SEM } & \multicolumn{3}{|c|}{ P-value ${ }^{\dagger}$} \\
\hline & SG & No SG & SG & No SG & & $\mathrm{SH}$ & SG & $\mathrm{SH} \times \mathrm{SG}$ \\
\hline Fibrobacter succinogenes & 0.068 & 0.099 & 0.065 & 0.089 & 0.005 & 0.36 & $<0.01$ & 0.44 \\
\hline Ruminococcus albus & $0.003^{\mathrm{c}}$ & $0.012^{\mathrm{b}}$ & $0.003^{\mathrm{c}}$ & $0.045^{\mathrm{a}}$ & 0.002 & $<0.01$ & $<0.01$ & $<0.01$ \\
\hline Ruminococcus flavefaciens & $0.002^{\mathrm{b}}$ & $0.008^{\mathrm{b}}$ & $0.015^{b}$ & $0.127^{\mathrm{a}}$ & 0.002 & $<0.01$ & $<0.01$ & $<0.01$ \\
\hline Anaerovibrio lipolytica & $0.018^{\mathrm{ab}}$ & $0.015^{\mathrm{b}}$ & $0.022^{\mathrm{a}}$ & $0.001^{\mathrm{c}}$ & 0.002 & 0.12 & $<0.01$ & $<0.01$ \\
\hline Selenomonas ruminantium & 0.031 & 0.023 & 0.033 & 0.006 & 0.001 & 0.03 & $<0.01$ & 0.4434 \\
\hline Total Archaeas & $0.083^{\mathrm{c}}$ & $0.278^{\mathrm{b}}$ & $0.017^{\mathrm{c}}$ & $0.803^{\mathrm{a}}$ & 0.051 & $<0.01$ & $<0.01$ & $<0.01$ \\
\hline
\end{tabular}

a,b, $=$ Means within a row with different superscripts (lower case) differ $(\mathrm{P}<0.05)$ by Tukey tests; ${ }^{\dagger=} \mathrm{SH}$, soybean hulls addition effect; $\mathrm{SG}$, whole soybean grain addition effect.

There were no interactions between $\mathrm{SH} \times \mathrm{SG}$ for Nitrogen $(\mathrm{N})$ intake, $\mathrm{N}$ excreted, and $\mathrm{N}$ retained (Table 7). However, $\mathrm{N}$ intake $\left(\mathrm{g}^{-1} \mathrm{~d}\right)$ was lower in animals supplemented with SG $(P=0.02)$. Steers supplemented with $\mathrm{SH}$ and with $\mathrm{SG}$ had greater fecal $\mathrm{N}$ excretion (\% of $\mathrm{N}$ intake) than animals supplemented with $\mathrm{SH}$ without SG $(P<0.01)$. In addition, the apparent $\mathrm{N}$ digested $(\%$ of $\mathrm{N}$ intake and $\mathrm{g}^{-1} \mathrm{~d}$ ) were greater in $\mathrm{SH}$ and without SG source than $\mathrm{SH}$ and with SG $(P \leq 0.02)$.

The production of rumen microbial nitrogen and microbial protein yield, estimated from the urinary excretion of purine derivatives, was not different among treatments $\left(\mathrm{g}^{-1} \mathrm{~d}\right)$ and $\left(\mathrm{g}^{-1} \mathrm{~kg}\right.$ TDN, Table 7$)$. 
Table 7. Effect of replacement of ground corn by soybean hulls (SH) associated or not to whole soybean grain (SG) on nitrogen $(\mathrm{N})$ balance and ruminal microbial protein yield in grazing Nellore steers during rainy season.

\begin{tabular}{|c|c|c|c|c|c|c|c|c|}
\hline \multirow{2}{*}{ Item } & \multicolumn{2}{|c|}{ No SH } & \multicolumn{2}{|c|}{$\mathrm{SH}$} & \multirow{2}{*}{ SEM } & \multicolumn{3}{|c|}{ P-value ${ }^{\dagger}$} \\
\hline & SG & No SG & SG & No SG & & $\mathrm{SH}$ & SG & $\mathrm{SH} \times \mathrm{SG}$ \\
\hline $\mathrm{N}$ intake, $\mathrm{g}^{-1} \mathrm{~d}$ & 268.80 & 278.40 & 252.28 & 316.80 & 23.68 & 0.47 & 0.02 & 0.08 \\
\hline \multicolumn{9}{|l|}{$\mathrm{N}$ excretion, $\mathrm{g}^{-1} \mathrm{~d}$} \\
\hline Urine & 86.40 & 98.51 & 81.54 & 109.04 & 15.13 & 0.85 & 0.11 & 0.52 \\
\hline Feces & 60.22 & 70.34 & 68.23 & 69.91 & 4.14 & 0.41 & 0.09 & 0.22 \\
\hline Total & 146.62 & 169.85 & 149.77 & 178.95 & 16.77 & 0.70 & 0.07 & 0.79 \\
\hline \multicolumn{9}{|c|}{$\mathrm{N}$ excretion, $\%$ of total $\mathrm{N}$ excretion } \\
\hline Urine & 58.92 & 57.99 & 54.42 & 60.09 & 3.38 & 0.92 & 0.69 & 0.22 \\
\hline Feces & 41.07 & 42.01 & 45.57 & 39.06 & 3.38 & 0.92 & 0.69 & 0.09 \\
\hline \multicolumn{9}{|c|}{$\mathrm{N}$ excretion, $\%$ of $\mathrm{N}$ intake } \\
\hline Urine & 33.51 & 33.91 & 32.20 & 35.15 & 4.86 & 0.99 & 0.65 & 0.73 \\
\hline Feces & $23.23^{\mathrm{ab}}$ & $25.41^{\mathrm{ab}}$ & $27.15^{\mathrm{a}}$ & $22.40^{\mathrm{b}}$ & 1.98 & 0.80 & 0.19 & $<0.01$ \\
\hline \multicolumn{9}{|c|}{ Apparent $\mathrm{N}$ digested } \\
\hline$g^{-1} d$ & $209.01^{\mathrm{ab}}$ & $208.11^{\mathrm{ab}}$ & $185.10^{\mathrm{b}}$ & $247.09^{\mathrm{a}}$ & 22.15 & 0.59 & 0.03 & 0.02 \\
\hline$\%$ of $\mathrm{N}$ intake & $76.70^{\mathrm{ab}}$ & $74.52^{\mathrm{ab}}$ & $72.81^{\mathrm{b}}$ & $77.50^{\mathrm{a}}$ & 1.98 & 0.80 & 0.19 & $<0.01$ \\
\hline \multicolumn{9}{|l|}{$\mathrm{N}$ retained } \\
\hline$g^{-1} d$ & 123.05 & 109.17 & 103.09 & 138.11 & 23.17 & 0.72 & 0.39 & 0.06 \\
\hline$\%$ of $\mathrm{N}$ intake & 43.30 & 40.75 & 40.64 & 42.51 & 5.59 & 0.92 & 0.91 & 0.52 \\
\hline$\%$ of digested $\mathrm{N}$ & 56.21 & 54.73 & 55.74 & 54.23 & 6.81 & 0.94 & 0.74 & 0.99 \\
\hline \multicolumn{9}{|l|}{ Microbial N, } \\
\hline $\mathrm{g}^{-1} \mathrm{~d}$ & 107.16 & 156.05 & 101.13 & 144.12 & 32.96 & 0.82 & 0.10 & 0.91 \\
\hline $\mathrm{g}^{-1} \mathrm{~kg} \mathrm{TDN}^{¥}$ & 17.62 & 22.14 & 18.03 & 18.51 & 3.79 & 0.72 & 0.42 & 0.52 \\
\hline \multicolumn{9}{|c|}{ Microbial protein yield } \\
\hline $\mathrm{g}^{-1} \mathrm{~d}$ & 666.12 & 974.05 & 632.10 & 903.17 & 206.00 & 0.82 & 0.10 & 0.91 \\
\hline $\mathrm{g}^{-1} \mathrm{~kg}^{\mathrm{TDN}} \mathrm{N}^{¥}$ & 110.01 & 138.11 & 113.17 & 116.00 & 23.70 & 0.72 & 0.42 & 0.52 \\
\hline
\end{tabular}

${ }^{¥}=$ Nutrient digestible total; ${ }^{\mathrm{a}, \mathrm{b}, \mathrm{c}=}$ Means within a row with different superscripts (lower case) $\operatorname{differ}(\mathrm{P}<0.05)$ by Tukey tests. ${ }^{\dagger=} \mathrm{SH}$, soybean hulls addition effect; SG, whole soybean grain addition effect.

\section{Discussion}

This study reveals that soybean hulls have a similar energy value comparable to ground corn when offered as a supplement to grazing steers during the rainy season, as indicated by the similar intake and rumen fermentation parameters of these sources of energy. However, the use of whole soybean grain in the feed supplement reduced intake, protozoa population, and F. succinogenes abundance. Thus, the hypothesis that soybean hulls combined with whole soybean grain could replace ground corn as a source of energy in grazing steers during the rainy season, without affecting adversely feed intake, fermentation parameters and ruminal microbiota was rejected.
There was not observed interaction between SH and SG on dry matter (DM) and nutrient intake probably due to similarity between energy source (corn and SH) in the feed supplements tested. When, these different energy sources were combined with crude protein from pasture (higher degradable protein in rumen) during the rainy season, resulted in better synchronism in the rumen, which increased numerically the efficiencies of microbial protein synthesis observed. In agreement with our data, McDonnell et al. (1982) reported that the different source of energy in diet (corn or SH) not affected DM intake and average daily gain.

Nonetheless, the addition of soybean grain (source of oil) in diet $(1.78 \%$ to $4.06 \%$ of $\mathrm{EE}$, 
intake of 0.18 to $0.35 \mathrm{~kg}^{-1}$ d) decreased the intake of DM (13.32\%) and OM (14.4\%). This may occurs because the inclusion of lipids in the diet of animals grazing pasture can induces a toxic effect on cellulolytic bacteria (e.g. $F$. succinogenes, $R$. albus and $R$. flavefaciens) by creating a physical barrier that impedes the activity of microorganisms, and consequently reduces feed intake and diet digestibility (SULLIVAN et al., 2004). Findings of Carvalho et al. (2017) also demonstrates a reduction on DM intake due to inclusion of whole soybean grain in the supplement of grazing Nellore steers under similar conditions, with an increment of +200 $\mathrm{g}^{-1} \mathrm{~d}$ of EE intake. Additionally, Neto et al. (2017) reported a DM intake and digestibility reduction when whole soybean grain was used in the supplement of grazing Nellore steers in dry season.

Our results suggest that $F$. succinogenes play an important role in the diet digestibility, having a high sensibility to lipids. Animals supplemented with SG exhibited less ruminal proportion of $F$. succinogenes, which can be related to the negative effects of lipid content in the SG supplementation on nutrient digestibility. Some feedlot studies with Nellore steers also reported reductions on $F$. succinogenes abundance, due soybean oil supplementation correlating its fibrolityc bacteria with diet digestibility (GRANJA-SALCEDO et al., 2016; GRANJA-SALCEDO et al., 2017b). In agreement with previous studies, our data demonstrate that animals supplemented with $\mathrm{SH}$ without SG increased DM (5.15\%), OM (5.87\%), and aNDF $(11.98 \%)$ digestibility. Growing beef cattle fed by diets with lipid inclusion indicates a feed intake and DM total tract digestibility decrement compared to control animals (BEAUCHEMIN; MCGINN, 2006; CARVALHO et al., 2017; NETO et al., 2017). Additionally, once the intake for whole soybean grain was approximately $1.2 \mathrm{~kg}^{-1} \mathrm{~d}$ in both groups supplemented with $\mathrm{SG}$, is important to consider that whole soybean grain could contains anti-nutritional factors such as trypsin inhibitor, phytic acid, oligosaccharides, among others, which decreases ruminal crude protein digestibility (TAGHINEJAD et al., 2009), and may interfere with protein and mineral utilization in ruminants digestive tract (SIDDHURAJU et al., 2002).

The higher abundance of $R$. albus and $R$. flavefaciens observed in steers supplemented with SH without SG may be correlated to the greater values of DM (5.15\%), OM (5.87\%), and aNDF $(11.98 \%)$ digestibility. These interactions may be due higher NDF associated to lower ether extract content of SH without SG supplement, that provide substrates to both Ruminococcus species, once proliferation of cellulolytic bacteria in the rumen would be correlated with the amount of digestible fiber in the diet (TAJIMA et al., 2001).

The polyunsaturated fatty acid (PUFA) toxicity is generally considered more severe with increasing intake of starch but not sugar under moderate inclusion rates (MARTEL et al., 2011). Toxicity of PUFA is more likely a result of metabolic interruption (depressed intracellular ATP and acyl CoA pools) rather than membrane toxicity (MAIA et al., 2010). The double bonds alter the shape of the molecule, such that linked unsaturated fatty acids disrupt the lipid bilayer structure (KEWELOH; HEIPEIPER, 1996). Henderson (1973) and Granja-Salcedo et al. (2017b) also found that a Ruminococcus sp. was sensitive to PUFA.

The ruminal $\mathrm{pH}$ values for all supplements ranged between 6.41 and 6.53 , which were within the range considered acceptable for fiber digestion (ØRSKOV; RYLE, 1990). The addition of SG in the supplements no alter rumen $\mathrm{pH}$ values because the concentrations of total VFA (BAILE; FORBES, 1974) was similar between supplement treatment. Then this result suggested that the glycerol released from triglycerides hydrolysis in diets with inclusion of SG that could be fermented (PATRA; YU, 2013) and favors the production of free short chain fatty acids in the rumen (BATEMAN; JENKINS, 1998), was no efficient in alter concentrations of total VFA and consequently reduce $\mathrm{pH}$ values. 
The observed increasing of Anaerovibrio lipolytica abundance in steers supplemented with SG (population 12 and 15 times higher than supplements with $\mathrm{SH}$ without SG, respectively), suggests that the growth of these gram-positive bacterium was stimulated, once, A. lipolytica have the capacity to hydrolyze triglycerides into glycerol and fatty acids (HARFOOT; HAZLEWOOD, 1997). This bacterium can rapidly ferment glycerol and is predominate in grazing animals receiving concentrate feeds containing triglycerides (LOURENÇO et al., 2010).

When expressed in absolute amounts, $\mathrm{N}$ intake was greater in animals supplemented without SG (297.74 $\left.\mathrm{g}^{-1} \mathrm{~d}\right)$. Consequently, the lower $\mathrm{N}$ intake resulted in lower ruminal $\mathrm{NH}_{3}-\mathrm{N}$ concentrations in animals that were supplemented with SG (12.46 $\mathrm{mg}^{-1} \mathrm{dL}$ ). The concentration of $\mathrm{NH}_{3}-\mathrm{N}$ in the rumen results from the balance between production, absorption and incorporation of amino $\mathrm{N}$ into microbial protein (RUSSELL et al., 1983). Animals supplemented with SG showed a decrease in ruminal $\mathrm{NH}_{3}-\mathrm{N}$ concentration of $10.03 \%$ and in energy intake of $12.66 \%$. Consequently, this reduction of $\mathrm{NH}_{3}-\mathrm{N}$ concentrations and energy intake suppressed microbial growth, such that the microbial protein yield was $289.5 \mathrm{~g}^{-1} \mathrm{~d}$ lower compared with animals without SG supplementation. This may be explained due to animals had a reduction of fermentable organic matter intake and probably energy availability for optimal microbial growth and efficiency, once lipids are not a source of energy for rumen bacteria (DOREAU; FERLAY, 1995).

In pasture-based systems, previous efforts to improve $\mathrm{N}$ capture have focused on improving energy supply to the rumen, with the objective of incorporating more ammonia into microbial protein and, thereby, increasing the AA flow to the small intestine (MILLER et al., 2001; SAIRANEN et al., 2005; MOORBY et al., 2006). In agreement with these studies, our results showed that intake of GE increased at $12.66 \%$ for animals supplemented without SG. Consequently, microbial protein yield also increased by $30.81 \%$ for these animals, that possibly increased the AA flow to the small intestine and could improve the performance.

Regarding volatile fatty acids, propionate would have been expected to increase with supplements without $\mathrm{SH}$, because fermentation of starch and sugars from corn promotes an increased production of propionate (VAN SOEST, 1994). However, when animals were supplemented with SH without SG, there was an increase of organic matter and fiber digestibility, which ultimately leads to an increase of VFA production and, thus, had no differences between $\mathrm{SH} \times \mathrm{SG}$ for concentrations of individual VFA. The higher concentrations of total VFA indicate the more efficient anaerobic fermentation, which may be due to increased organic matter and fiber digestibility (KHATTAB et al., 2011).

The greater number of Entodinium in animals supplemented without SH without SG probably occur due a great adaptability to diets with high inclusion of starch (HOOK et al., 2011; GRANJASALCEDO et al., 2016). Ciliate protozoa play a vital role in rumen fermentation, once that exert a protection of easily fermentable carbohydrates (sugars and starch) from sugar-starch utilizing bacteria (KAMRA, 2005) so that organic acids are not produced in plenty immediately after the feeding of animals. However, these sugars are released slowly during the day so that there is a constant supply of energy for animals in the form of short chain volatile fatty acids.

On the other hand, SG supplementation decreased the numbers of Dasytricha, Isotricha, and total protozoa. The suppression effect of diet lipids on protozoa has been reported previously (CZERKAWSKI et al., 1975; BEAUCHEMIN et al., 2008) and is probably due to the UFA toxicity (CZERKAWSKI, 1973). This result is in agree with studies of Hristov et al. (2004) who reported that protozoa are sensitive to C18:3, C18:2, and C18:1. In Nellore steers also was observed a directly inhibition of ruminal protozoa and Archaea by diets containing soybean oil sources 
(GRANJA-SALCEDO et al., 2017c). Was observed an interaction between $\mathrm{SH} \times \mathrm{SG}$ supplements on ruminal Archaea abundance. Nonetheless, the effect more pronounced was for SH supplements without SG, since, the population of Archaea was increased by $84.32 \%$ when compared with SG supplements. These results are due to different factors such as defaunation effect of lipids in protozoa, which works symbiotically with Archaea, participating in transfers of hydrogen, which is used to reduce $\mathrm{CO}_{2}$ to $\mathrm{CH}_{4}$ (NEWBOLD et al., 1995). The other factors that reducing the activity of Archaea was the UFA content in SG, whose can also reduce the concentration of hydrogen in the rumen by means of biohydrogenation, acting as sink of hydrogen (CZERKAWSKI, 1972). In addition, studies showed that Archaea are susceptibility to PUFA (HOOK et al., 2010).

\section{Conclusions}

A greater understanding of microbial variation that accompanies beneficial dietary changes will lead to novel strategies to modulate rumen to increase efficiency of animal production. The use of soybean hulls without soybean grain in the supplement may be effective to increase digestibility of DM and nutrient, $\mathrm{N}$ retained, $R$. albus and $R$. flavefaciens in the rumen of growing Nellore steers grazing Brachiaria brizantha cv. Xaraés during the rainy season. However, the inclusion of soybean grain in the supplement is not recommended because may reduce DM intake, protozoa population, F. succinogenes abundance, and microbial protein yield in the rumen. The implications of this study are the nutritional factors to be considered in the productive systems of grazing animals during rainy season. In addition, to the correct management of tropical forages, the use of concentrate supplementation with SH without SG can be a technology importance to keep metabolism balance, which contributes to better digestibility of nutrient in rainy season.

\section{Acknowledgement}

We thank the São Paulo Research Foundation (FAPESP, Brazil) grant numbers 2011/00060-8, 2012/08284-5, 2013/23851-6, 2014/09033-1 and 2017/02034-0 for supported this research.

\section{References}

ALLEN, V. G.; BATELlO, C.; BERRETTA, E. J.; HODGSON, J.; KOTHMANN, M.; LI, X.; MCIVOR, J.; MILNE, J.; MORRIS, C.; PEETERS, A.; SANDERSON, M. An international terminology for grazing lands and grazing animals. Grass and Forage Science, Oxford, v. 66 , n. 1, p. 22-28, 2011. Doi: 10.1111/j.13652494.2010.00780.x

ASSOCIATION OF OFFICIAL ANALYTICAL CHEMISTS - AOAC. Official methods of analysis. $15^{\text {th }}$ ed. Arlington: AOAC, 1990.

BAILE, C. A.; FORBES, M. J. Control feed intake and regulation of energy balance in ruminants, Physiological Reviews, v. 54, n. 1, p.160-214, 1974. DOI: 10.1152/ physrev.1974.54.1.160

BARROS, E. E. L.; FONTES, C. A. A.; DETMAN, E.; VIEIRA, R. A. M.; HENRIQUES, L. T.; FERNANDES, A. M. Vícios na estimação da excreção fecal utilizando indicadores internos e óxido crômico em ensaios de digestão com ruminantes. Revista Brasileira de Zootecnia, Viçosa, v. 38, n. 10, 2015-2020, 2009. DOI: 10.1590/S1516-35982009001000023

BARTHRAM, G.T. 1985. Experimental techniques: the HFRO sward stick. In: The hill Farming Research Organization Biennial Report 1984/1985. Penicuik: Hill Farming Research Organization, 1985. p. 29-30.

BATEMAN, H. G.; JENKINS, T. C. Influence of soybean oil in high fiber diets fed to nonlactating cows on ruminal unsaturated fatty acids and nutrient digestibility, Journal of Dairy Science, Champaign, v. 81, n. 9, p. 2451-2458, 1998. DOI: $10.3168 /$ jds.S0022-0302(98)70136-5

BEAUCHEMIN, K. A.; KREUZER, M.; O'MARA, F.; MCALLISTER, T. A. Nutritional management for enteric methane abatement: A review, Australian Journal of Experimental Agriculture, Melbourne, v. 48, n. 2, p. 21-27, 2008. DOI: 10.1071/EA07199

BEAUCHEMIN, K. A.; MCGINN, S. M. Methane emissions from beef cattle: effects of fumaric acid, essential oil, and canola oil. Journal of Animal Science, Champaign, v. 84, n. 6, p.1 489-1496, 2006. DOI: $10.2527 / 2006.8461489 \mathrm{x}$ 
CARVALHO, I. P. C.; FIORENTINI, G.; CASTAGNINO, P. S.; JESUS, R. B.; MESSANA, J. D.; GRANJASALCEDO, Y. T.; DETMANN, E.; PADMANABHA, J.; MCSWEENEY, C. S.; BERCHIELLI, T. T. Supplementation with lipid sources alters the ruminal fermentation and duodenal flow of fatty acids in grazing Nellore steers. Animal Feed Science Technology, Viçosa, v. 227, p.142-153, 2017. DOI: 10.1016/j. anifeedsci.2017.02.017

CHEN, X. B.; GOMES, M. J. Estimation of microbial protein supply to sheep and cattle based on urinary excretion of purine derivatives - an overview of technical details, international feed resources unit. Aberdeen: Rowett Research Institute, 1992.

CHIZZOTTI, M. L.; VALADARES FILHO, S. de C.; VALADARES, R. F. D.; CHIZZOTTI, F. H. M.; TEDESCHI, L.O. Determination of creatinine excretion and evaluation of spot urine sampling in Holstein cattle. Livestock Science, Amsterdam, v. 113, n. 2-3 p. 218-225, 2008. DOI: 10.1016/j.livsci.2007.03.013

CORRIGAN, M. E.; ERICKSON, G. E.; KLOPFENSTEIN, T. J.; LUEBBE, M. K.; VANDER POL, K. J.; MEYER, N. F.; BUCKNER, C. D.; VANNESS, S. J.; HANFORD, K. J. Effect of corn processing method and corn wet distillers grains plus solubles inclusion level in finishing steers, Journal of Animal Science, Champaign, v. 87, n. 10, p. 3351-3362, 2009. DOI: $10.2527 /$ jas.2009-1836

COSTA E SILVA, L. F.; VALADARES FILHO, S. de C.; CHIZZOTTI, M. L.; ROTTA, P. P.; PRADOS, L. F.; VALADARES, R. F. D.; ZANETTI, D.; BRAGA, J. M. D. S. Creatinine excretion and relationship with body weight of Nellore cattle, Revista Brasileira de Zootecnia, Viçosa, v. 41, n. 3, p. 807-810, 2012. DOI: 10.1590/ S1516-35982012000300046

CZERKAWSKI, J. W. Fate of metabolic hydrogen in the rumen, The Proceedings of the Nutrition Society, London, v. 31, n. 2, p.141-146, 1972.

CZERKAWSKI, J. W. Effect of linseed oil fatty acids and linseed oil on rumen fermentation in sheep, Journal of Agriculture Science, London, v. 81, n. 3, p. 517-531, 1973. DOI: $10.1017 / \mathrm{S} 0021859600086573$

CZERKAWSKI, J. W.; CHRISTIE, W. W.; BRECKENRIDGE, G.; HUNTER, M. L. Changes in rumen metabolism of sheep given increasing amounts of linseed oil in their diet, British Journal of Nutrition, Cambridge, v. 34, n. 1, p. 25-44, 1975. DOI: 10.1017/ s0007114575000074

D'AGosto, M. T.; CARNEIRO, M. E. Evaluation of lugol solution used for counting rumen ciliates, Revista
Brasileira de Zoologia, São Paulo, v. 16, n. 3, p. 725-729, 1999. DOI: 10.1590/S0101-81751999000300011

DEHORITY, B. A. Evaluation of subsampling and fixation procedures used for counting rumen protozoa. Applied Environmental Microbiology, Washington, v. 48, n. 4, p. 182-185, 1984.

DENMAN, S. E., MCSWEENEY, C. S. Development of a real-time PCR assay for monitoring anaerobic fungal and cellulolytic bacterial populations within the rumen. FEMS Microbiology Ecology, Amsterdam, v. 58, n. 3, p. 572-582, 2006. DOI: 10.1111/j.1574-6941.2006.00190.x

DENMAN, S. E.; TOMKINS, N.; MCSWEENEY, C. S. Quantitation and diversity analysis of ruminal methanogenic populations in response to the antimethanogenic compound bromochloromethane. FEMS Microbiology Ecology, v. 62, n. 3, 313-322, 2007. doi: 10.1111/j.1574-6941.2007.00394.x

DOREAU, M.; FERLAY, A. Effect of dietary lipids on nitrogen metabolism in the rumen. A review, Livestock Science, Amsterdam, v. 43, n. 2, p. 97-110, 1995. DOI: 10.1016/0301-6226(95)00041-I

DROUILLARD, J. S., Utilization of crude glycerin in beef cattle. In: MAKKAR, H. P. S. (Ed.). Biofuel coproducts as livestock feed - opportunities and challenges. Rome: Food and agriculture organization of the United Nation, 2012. p. 155-161

FENNER, H. Methods for determining total volatile bases in rumen fluid by steam distillation. Journal of Dairy Science, Champaign, v. 48, p. 249-251, 1965. DOI: 10.3168/jds.S0022-0302(65)88206-6

FUENTES, M. C.; CALSAMIGLIA, S.; CARDOZO, P. W.; VLAEMINCK, B. Effect of $\mathrm{pH}$ and level of concentrate in the diet on the production of biohydrogenation intermediates in a dual-flow continuous culture. Journal of Dairy Science, v. 92, n. 2, p. 4456-4466, 2009. DOI: 10.3168/jds.2008-1722

GOMEZ-INSUASTI, A. S.; GRANJA-SALCEDO, Y. T.; CASTAGNINO, P. S.; VIEIRA, B. R.; MALHIEROS, E. B.; BERCHIELLI, T. T. The effect of lipid sources on intake, rumen fermentation parameters and microbial protein synthesis in Nellore steers supplemented with glycerol. Animal Production Science, Melbourne, v. 54, n. 10, p. 1871-1876, 2014. DOI: 10.1071/AN14394

GOMEZ-INSUASTI, A. S.; GRANJA-SALCEDO, Y. T.; ROSSI, L. G.; VIEIRA, B. R.; BERCHIELLI, T. T. Effect of soybean oil availabilities on rumen biohydrogenation and duodenal flow of fatty acids in beef cattle fed a diet with crude glycerine, Archives of Animal Nutrition, Abingdon, v.72, n. 4, p. 308-320, 2018. DOI: $10.1080 / 1745039 X .2018 .1492805$ 
GRANJA-SALCEDO, Y. T.; MESSANA, J. D.; SOUZA V. C.; DIAS, L. A. V.; KISHI, L. T.; REBELO, L. R.; BERCHIELLI, T. T. Effects of partial replacement of maize in the diet with crude glycerin and/or soyabean oil on ruminal fermentation and microbial population in Nellore steers. British Journal of Nutrition, v. 118, n. 9, p. 651-660, 2017c. DOI: $10.1017 / \mathrm{S} 0007114517002689$

GRANJA-SALCEDO, Y. T.; RAMIREZ-USCATEGUI, R. A.; MACHADO, E. G.; MESSANA, J. D.; KISHI, L. T.; DIAS, A. V. L.; BERCHIELLI, T. T. Studies on bacterial community composition are affected by the time and storage method of the rumen content. Plos One, San Francisco, v. 12, n. 4, e0176701, 2017a. DOI: 10.1371/ journal.pone.0176701

GRANJA-SALCEDO, Y. T.; RIBEIRO C. S. J.; JESUS, R. B. de; GOMEZ-INSUASTI, A. S.; RIVERA, R. A.; MESSANA, J. D.; CANESIN, R. C; BERCHIELLI, T. $\mathrm{T}$. Effect of different levels of concentrate on ruminal microorganisms and rumen fermentation in Nellore steers, Archives of Animal Nutrition, v. 70, n. 1, p. 17-32, 2016. DOI: 10.1080/1745039X.2015.1117562

GRANJA-SALCEDO. Y. T.; SOUZA, V. C.; DIAS, L. A. V.; GOMEZ-INSUASTI, A. S.; MESSANA, J. D.; BERCHIELLI, T.T.Diet containing glycerine and soybean oil can reduce ruminal biohydrogenation in Nellore steers. Animal Feed Science and Technology, v. 225, p. 195-204, 2017b. DOI: 10.1016/j.anifeedsci.2017.01.021

HARFOOT, C. G.; HAZLEWOOD, G. P. Lipid metabolism in the rumen. In: HOBSON P. N.; STEWART, C. S. (Ed.). The rumen microbial ecosystem. London: Chapman and Hall, 1997.

HENDERSON, C. The effects of fatty acids on pure cultures of rumen bacteria. The Journal of Agriculture Science, London, v. 81, n. 1, p.107-112, 1973. DOI: $10.1017 / \mathrm{S} 0021859600058378$

HOOK, E. S.; STEELE, A. M.; NORTHWOOD, S. K.; WRIGHT, G. A. D.; MCBRIDE, W. B. Impact of highconcentrate feeding and low ruminal $\mathrm{pH}$ on methanogens and protozoa in the rumen of dairy cows. Microbial Ecology, New York, v. 62, n. 1, p. 94-105, 2011. DOI: 10.1007/s00248-011-9881-0

HOOK, S. E.; WRIGHT, A. D. G.; MCBRIDE, B. W. Methanogens: methane producers of the rumen and mitigation strategies. Archaea, Victoria, v. 2010, 945785 , 2010. DOI: $10.1155 / 2010 / 945785$

HRISTOV, A. N.; IVAN, M.; MCALLISTER, T. A. In vitro effects of individual fatty acids on protozoal numbers and on fermentation products in ruminal fluid from cattle fed a high concentrate, barley-based diet. Journal of Animal Science, Champaign, v. 82, n. 9, p. 2693-2704, 2004. DOI: 10.2527/2004.8292693x
JENKINS, T. C. Lipid metabolism in the rumen. Journal of Dairy Science, Champaign, v. 76, n. 12, p. 3851-3863, 1993. DOI: $10.3168 /$ jds.S0022-0302(93)77727-9

JOHNSON, A. D. Sample preparation and chemical analysis of vegetation. In: MANEJTE, L. T. (Ed.). Measurement of grassland vegetation and animal production. Aberustwysth: Commonweath Agricultural Bureax, 1978. p. 96-102.

KAMRA, D. N. Rumen microbial ecosystem. Current Science, Bangalore, v. 89, n. 1, p.124-135, 2005.

KEWELOH, H.; HEIPIEPER, H. J. Trans unsaturated fatty acids in bacteria. Lipids, Chicago, v. 31, n. 2, p. 129137, 1996. DOI: $10.1007 /$ bf02522611

KHAFIPOUR, E.; LI, S.; PLAIZIER, J. C.; KRAUSE, D. O. (2009). Rumen microbiome composition determined using two nutritional models of subacuteruminal ácidosis. Applied Environmental Microbiology, v. 75, n. 22, p. 7115-7124. DOI: 10.1128/AEM.00739-09

KHATTAB, H. M.; GADO, H. M.; KHOLIF, A. E.; MANSOUR, A. M.; KHOLIF, A. M. The potential of feeding goats sun dried rumen contents with or without bacterial inoculums as replacement for berseem clover and the effects on milk production and animal health. Journal of Dairy Science, Champaign, v. 6, n. 5, p. 267277, 2001. DOI: 10.3923/ijds.2011.267.277

LOURENÇO, M.; RAMOS M. E.; WALLACE, R. J. The role of microbes in rumen lipolysis and biohydrogenation and their manipulation. Animal, Cambridge, v. 4, n. 7, p. 1008-1023, 2010. DOI: 10.1017/S175173111000042X

MAIA, M. R.; CHAUDHARY, L. C.; BESTWICK, C. S.; RICHARDSON, A. J.; MCKAIN, N.; LARSON, T. R.; GRAHAM, I. A.; WALLACE, R. J. Toxicity of unsaturated fatty acids to the biohydrogenating ruminal bacterium, Butyrivibrio fibrisolvens. BMC microbiology, London, v. 10, n. 10, p. 52, 2010. DOI: 10.1186/14712180-10-52

MARTEL, C. A.; TITGEMEYER, E. C.; MAMEDOVA, L. K.; BRADFORD, B. J. Dietary molasses increases ruminal $\mathrm{pH}$ and enhances ruminal biohydrogenation during milk fat depression. Journal of Dairy Science, Champaign, v. 94, n. 3, p. 3995-4004, 2011. DOI: 10.3168/jds.2011-4178

MCDONNELL, M. L.; KLOPFENSTEIN, T. J.; MERRILL, J. K. Soybean hulls as energy source for ruminants. Nebraska Beef Cattle Reports, Lincoln, v. 43, p. 54-56, 1982.

MILLER, L. A.; MOORBY, J. M.; DAVIES, D. R.; HUMPHREYS, M. O.; SCOLLAN, N. D.; MACRAE, J. C.; THEODOROU, M. K; Increased concentration of water-soluble carbohydrate in perennial ryegrass (Lolium 
perenne L.): Milk production from late-lactation dairy cows. Grass and Forage Science, Oxford, v. 56, n. 4, p. 383-394, 2001. DOI: 10.1046/j.1365-2494.2001.00288.x

MOORBY, J. M.; EVANS, R. T.; SCOLLAN, N. D.; MACRAE, J. C.; THEODOROU, M. K. Increased concentration of water-soluble carbohydrate in perennial ryegrass (Lolium perenne). Evaluation in dairy cows in early lactation. Grass and Forage Science, Oxford, v. 61 , n. 1, p. 52-59, 2006. DOI: $10.1111 / \mathrm{j} .1365-$ 2494.2006.00507.x

NETO, A. J.; MESSANA, J. D.; GRANJA-SALCEDO, Y. T.; CASTAGNINO, P. S.; FIORENTINI, G.; REIS, R. A.; BERCHIELLI, T. T. Effect of starch level in supplement with or without oil source on diet and apparent digestibility, rumen fermentation and microbial population of Nellore steers grazing tropical grass. Livestock Science, v. 202, 171-179, 2017. DOI: 10.1016/j. livsci.2017.06.007

NEWBOLD, C. J.; LASSALAS, B.; JOUANY, J. P. The importance of methanogens associated with ciliate protozoa in ruminal methane production in vitro. Letters in Applied Microbiology, Oxford, v. 21, n. 4, p. 230-234, 1995. DOI: 10.1111/j.1472-765X.1995.tb01048.x

NATIONAL RESEARCH COUNCIL'S - NRC. Nutrient requirements of beef cattle. 7. ed. Washington: The National Academies Press, 2000.

ØRSKOV, E. R.; MACLEOD, N. A. Dietary-induced thermogenesis and feed evaluation in ruminants. Proceedings of the Nutrition Society, London, v. 49, n. 2, p. 227-237, 1990. DOI: 10.1079/PNS19900026

PALMQUIST, D. L.; CONRAD, H. R. Origin of plasma fatty acids in lactating cows fed high grain or high fat diets. Journal of Dairy Science, Champaign, v. 54, n. 7 , p. $1025-1033$, 1971. DOI: 10.3168/jds.S00220302(71)85966-0

PARSONS, G. L.; SHELOR, M. K.; DROUILLARD, J.S. Performance and carcass traits of finishing heifers fed crude glycerin. Journal of Animal Science, Champaign, v. 87, n. 2, p. 653-657, 2009. DOI: $10.2527 /$ jas.2008-1053

PATRA, A. K.; YU, Z. Effects of coconut and fish oils on methane production, fermentation, abundance and diversity of rumen microbial populations in vitro. Journal of Dairy Science, Champaign, v. 96, n. 3, p. 1782-1792, 2013. DOI: $10.3168 /$ jds.2012-6159

POPP, J.; LAKNER, Z.; HARANGI-RÁKOS, M.; FÁRI, $M$. The effect of bioenergy expansion: food, energy, and environment, Renewable \& Sustainable Energy Reviews, Amsterdam, v. 32, p. 559-578, 2014. DOI: 10.1016/j. rser.2014.01.056

RUSSELL, J. B.; SNIFFEN, C. J.; VAN SOEST, P. J.
Effect of carbohydrate limitation on degradation and utilization of casein by mixed rumen bacteria. Journal of Dairy Science, Champaign, v. 66, n. 4, p. 763-775, 1983. DOI: 10.3168/jds.S0022-0302(83)81856-6

SAIRANEN, A.; KHALILI, H.; NOUSIAINEN, J. I.; AHVENJARVI, S.; HUHTANEN, P. The effect of concentrate supplementation on nutrient flow to the omasum in dairy cows receiving freshly cut grass. Journal of Dairy Science, Champaign, v. 88, n. 4, p. 1443-1453, 2005. DOI: $10.3168 /$ jds.S0022-0302(05)72812-5

SALIBA, E. O. S.; GONÇALVES, N. C.; BARBOSA, G. S. S. C.; BORGES, A. L. C. C.; RODRIGUEZ, N. M.; MOREIRA, G. R.; SILVA, F. A. Evaluation of the infrared spectroscopy method for the quantification of nanolipe marker in feces of dairy cattle. In: OLTJEN, J. W.; KEBREAB, E.; LAPIERRE, H. Energy and protein metabolism and nutrition in sustainable animal production. California: Wageningen Academic Publisher, 2013. p. 247-248.

SANTOS, S. A.; VALADARES FILHO, S. de C.; DETMANN, E.; VALADARES, R. F. D.; RUAS, J. R. M.; AMARAL, P. M. Different forage sources for F1 Holstein $\times$ Gir dairy cows. Livestock Science, Amsterdam, v. 142, n. 1-3, p. 48-58, 2011. DOI: 10.1016/j.livsci.2011.06.017

SCHRÖDER,A.; SÜDEKUM, K.H.; SCHOONMAKER, J. P.; CECAVA, M. J.; FAULKNER D. B.; FLUHARTY, F. L.; ZERBY, H. N.; LOERCH, S. C. Effect of source of energy and rate of growth on performance, carcass characteristics, ruminal fermentation, and serum glucose and insulin of early-weaned steers. Journal of Animal Science, Champaign, v. 81, n. 4, p. 843-855, 2003. DOI: $10.2527 / 2003.814843 \mathrm{x}$

SIDDHURAJU, P.; MAKKAR, H. P. S.; BECKER, K. The effect of ionising radiation on antinutritional factors and the nutritional value of plant materials with reference to human and animal food. Food Chemistry, Norwich, v. 78 , n. 2 , p. $187-205$, 2002. DOI: $10.1016 / \mathrm{S} 0308-$ 8146(01)00398-3

SULLIVAN, H. M.; BERNARD, J. K.; AMOS, H. E.; JENKINS, T. C. Performance of lactating dairy cows fed whole cottonseed with elevated concentrations of free fatty acids in the oil. Journal of Dairy Science, Champaign, v. 87 , n. 3, p. 665-671, 2004. DOI: $10.3168 /$ jds.S0022-0302(04)73209-9

TAGHINEJAD, M.; NIKKHAH, A.; SADEGHI, A. A.; RAISALI, G.; CHAMANI, M. (2009) Effects of gamma irradiation on chemical composition, antinutritional factors, ruminal degradation and in vitro protein digestibility of full-fat soybean. Asian-Australasian Journal of Animal Sciences, v. 22, n. 4, p. 534-541. DOI: 10.5713/ajas.2009.80567 
TAJIMA, K.; AMINOV, R. I.; NAGAMINE, T.; MATSUI, H.; NAKAMURA, M.; BENNO, Y. Dietdependent shifts in the bacterial population of the rumen revealed with real-time PCR. Applied and environmental microbiology, Washington, v. 67, n. 6, p. 2766-2774, 2001. DOI: 10.1128/AEM.67.6.2766-2774.2001

VALADARES, R. F. D.; BRODERICK, G. A.; VALADARES FILHO, S. C.; CLAYTON, M. K. Effect of replacing alfalfa silage with high moisture corn on ruminal protein synthesis estimated from excretion of total purine derivatives. Journal of Dairy Science, Champaign, v. 82 , n. 12 , p. $2686-2699$, 1999. DOI: 10.3168/jds.S0022-0302(99)75525-6

VALADARES FILHO, S. de C., MACHADO, P. A. S., CHIZZOTTI, M. L., AMARAL, H. F., MAGALHÃES, C. A., ROCHA JÚNIOR, V. R.; CAPELLE, E. R. CQBAL 3.0. Brazilian tables of the chemical composition of feeds for ruminants. 2010. Available at: https://scholar.google. com.br/citations? user=2kR2DtgAAAAJ\&hl=pt-BR. Accessed at: 20 set. 2019.
VALENTE, T. N. P.; DETMANN, E.; QUEIROZ, A. C.; VALADARES FILHO, S. C.; GOMES, D. I.; FIGUEIRAS, J. F. Evaluation of ruminal degradation profiles of forages using bags made from different textiles. Revista Brasileira de Zootecnia, viçosa, v. 40 , v. 10 , p. $2565-2573$, 2011. DOI: $10.1590 / \mathrm{S} 1516-$ 35982011001100039

VAN SOEST, P. J. (1994). Nutritional ecology of the ruminant. 2. ed. New York: Cornell University Press.

VAN SOEST, P. J.; ROBERTSON, J. B.; LEW, B. A. Methods for dietary fiber, neutral detergent fiber, and nonstarch polysaccharides in relation to animal nutrition. Journal of Dairy Science, Champaign, v. 74, n. 10 , p. $3583-3597,1991$. DOI: $10.3168 /$ jds.S00220302(91)78551-2 